\title{
DETERMINANTS OF SELF-ASSESSMENT OF PHYSICAL FITNESS IN PERSONS AGED 45-89
}

\section{DETERMINANTY SAMOOCENY SPRAWNOŚCI FIZYCZNEJ OSÓB W WIEKU 45-89 LAT}

\author{
Katarzyna Kotarska ${ }^{1(\mathrm{~A}, \mathrm{~B}, \mathrm{E}, \mathrm{F}, \mathrm{G})}$, Maria Alicja Nowak ${ }^{1(\mathrm{~A}, \mathrm{~B}, \mathrm{C}, \mathrm{D}, \mathrm{E})}$
}

${ }^{1}$ Department of Physical Culture and Health Promotion, University of Szczecin, Poland

Authors' contribution Wkład autorów:

A. Study design/planning zaplanowanie badań

B. Data collection/entry zebranie danych

C. Data analysis/statistics dane - analiza i statystyki D. Data interpretation interpretacja danych E. Preparation of manuscript przygotowanie artykułu F. Literature analysis/search wyszukiwanie i analiza literatury G. Funds collection zebranie funduszy
Tables: 3

Figures: 2

References: 30

Submitted: 2017 May 20

Accepted: 2017 Aug 25

\section{Summary}

Background. Scientific studies on ageing have repeatedly shown positive correlations between physical activity and physical fitness and health. The following study shows that people who were involved in different forms of physical activity had higher self-assessment of own fitness, also in the long term. The aim of the study was to investigate the determinants of the self-assessment of physical fitness in people aged 45-89 years.

Material and methods. The study involved 300 persons aged 45-89 years, who were diagnosed with a diagnostic survey using the following research techniques: a questionnaire, interview and observation. The qualitative and quantitative analyses were based on the frequency of traits, chi-square independence tests, and multivariate correspondence analyses.

Results. Self-assessment of physical fitness depended on age, family roles and employment status. Higher levels of fitness were reported by (i) respondents engaged in recreational exercise and (ii) former professional athletes. Going on holidays in the previous year, travelling in the past and at present were also correlated with higher self-assessment of physical fitness.

Conclusions. Self-assessment of physical fitness seems to be a good indicator of the physical activity in the elderly. Positive self-assessment helps address the challenges of old age and seems to be crucial for successful ageing. Hence, there is a need to create programmes with a broader spectrum of influence to activate the elderly.

Keywords: elderly, self-assessment of physical activity, travelling

\section{Streszczenie}

Wprowadzenie. W badaniach naukowych, dotyczących procesu starzenia się, wielokrotnie wykazywano pozy tywne związki aktywności fizycznej ze sprawnością fizyczną i zdrowiem. Osoby podejmujące różne formy aktywności fizycznej cechowała wyższa samoocena sprawności fizycznej, także w perspektywie długoterminowej. Celem pracy było poznanie uwarunkowań samooceny sprawności fizycznej osób w wieku 45-89 lat.

Materiał i metoda. Badaniami objęto 300 osób w wieku 45-89 lat. Zastosowano metodę sondażu diagnostycznego, z wykorzystaniem technik badawczych: kwestionariusza ankiety, wywiadu i obserwacji. W analizach jakościowych i ilościowych użyto: frekwencję cech, test niezależności chi-kwadrat oraz wielowymiarową analizę korespondencji.

Wyniki. Samoocena sprawności fizycznej badanych uwarunkowana była ich wiekiem, pełnieniem ról rodzinnych oraz aktywnością zawodową. Wyższą samooceną sprawności fizycznej cechowały się osoby, które obecnie podejmowały rekreacyjnie wysiłek fizyczny, a w przeszłości uprawiały sport wyczynowy. Respondenci wyjeżdżający na wczasy w ostatnim roku, odbywający podróże w przeszłości i obecnie mieli wyższe samooceny sprawności fizycznej.

Wnioski. Samoocena sprawności fizycznej wydaje się być dobrym wskaźnikiem zróżnicowanej aktywności fizycznej osób starszych. Pozytywna samoocena sprawności fizycznej wpływa na możliwości podejmowania nowych wyzwań, które maja istotne znaczenie w przebiegu procesu pomyślnego starzenia się. Istnieje zatem potrzeba tworzenia programów aktywizacji seniorów o szerokim spektrum.

Słowa kluczowe: osoby starsze, samoocena sprawności fizycznej, aktywność fizyczna, podróżowanie 


\section{Introduction}

Ageing usually leads to a significant decrease in physical activity and physical fitness, significantly affecting the ability to perform daily activities and reducing self-reliance [1]. This is related to the changes in the musculoskeletal system, loss of muscle strength, impaired motor coordination, and reduction in cardiovascular performance. Studies show that increased susceptibility to fractures and fear of falling [2] can seriously affect successful ageing.

The physical activity of Poles, especially those 80+, is not impressive compared to other EU countries. The most active are Scandinavians, especially Swedes, with the highest percentage of centenarians [3]. However, the phenomenon of longevity is more complicated. Usually, it is women who live longer, regardless of their place of residence and lower activity than in men [4]. Self-reliance seems to be the basis for satisfactory ageing. It depends on good health, which in turn depends not only on genetic factors but also on appropriate pro-health behaviours. Unfortunately, the elderly usually reduce physical activity to the most necessary daily activities such as shopping, cooking, or cleaning. Relatively high physical activity in the old age is a factor guaranteeing a longer and better life. It allows for maintaining autonomy, keeping in shape for many years and maintaining a high quality of life [5,6]. Physical activity is directly related to the sphere of everyday life but also helps meet other psychological needs. In addition, it is one of the most important modifiable risk factors for many diseases [7,8]. Finally, good health and physical activity are essential for professional and social competencies that determine the quality of life [9]. Physical fitness is ensured solely by physical activity, an indispensable element of pro-health prevention measure, and part of treatment in many diseases. Scientific studies have often proved the beneficial effect of moderate physical activity on physical fitness and health [10] and the self-assessment of physical fitness and health [11,12]. Those who systematically exercise also perceive their health status positively, as well as experience a better physical and mental well-being $[13,14]$. For example, in an exercise programme for 235 adult and elderly Belgians, there was a significant effect of physical activity on the total self-assessment (improved physical fitness, physical competences, and attractiveness), both in the short- and long-term [15].

Positive self-assessment is perceived not only as the primary element of mental health, but also as a preventive measure, protecting against the effect of negative behaviours and habits, and contributing to the improved health and positive social actions. Low self-assessment is often associated with the low level of prohealth behaviours and usually deteriorates with age [16]. Positive self-assessment of physical fitness influences the ability to undertake various actions and reflects self-esteem. It has a crucial role in successful ageing as a marker of multiple health dimensions (physical, psychological, social, and spiritual). Self-assessment is also an element of self-knowledge [13]. It includes physical health, mental state, social relations, self-reliance, and perception of the environment. Relating to the broad field of human experience, it depends on numerous factors, such as financial status, occupation, health status, living conditions, personal relations, political and cultural climate, environmental conditions, and physical activity. Researchers emphasise that the ability to self-assess own physical fitness is a significant educational achievement [17].

The aim of this paper was to establish the determinants of self-assessment of physical activity in persons aged 45-89.

\section{Material and methods}

For the past few years, research on the physical activity of the elderly has been conducted in the Department of Physical Culture of the Poznań Academy of Physical Education in Gorzów Wielkopolski and the Faculty of Physical Culture and Health Promotion in the University of Szczecin. As part of the physical, social and cultural activation of the elderly, students interviewed their parents and grandparents using a specially prepared questionnaire. The results were used to design an exercise programme corresponding to the needs of the respondents. The study, using a purposeful sampling, involved 300 adults and the elderly. The sample group was divided into three age categories: 45-59 years (mature age), 60-74 years (early old age) and 75-89 years old (late old age).

The study was conducted as a diagnostic survey using a questionnaire and interview. The information obtained was supplemented by observations and non-categorised interviews conducted in students. The qualitative and quantitative analysis was performed using standard statistical methods: frequency of traits, chi-square independence tests, and correspondence analyses [18]. The analyses used Statistica 12 software [StatSoft, Inc. 2015 Statistica for Windows]. Statistical significance of the studied relationships was set at $\mathrm{p} \leq 0.05$. 


\section{Results}

The self-assessment of own physical fitness was analysed against the demographic variables (Table 1).

Table 1. Demographic determinants of physical fitness in the respondents ( $\chi^{2}$ test of independence)

\begin{tabular}{|c|c|c|c|c|c|c|c|}
\hline \multirow[b]{2}{*}{ Characteristics } & \multicolumn{4}{|c|}{ Self-assessment of physical fitness (\%) } & \multicolumn{2}{|c|}{ Total $(n=300)$} & \multirow[b]{2}{*}{$p$ for the $\chi^{2}$ test } \\
\hline & $\begin{array}{l}\text { High } \\
\text { (35) }\end{array}$ & $\begin{array}{c}\text { Moderate } \\
\text { (191) }\end{array}$ & $\begin{array}{l}\text { Low } \\
(66)\end{array}$ & $\begin{array}{c}\text { I don't } \\
\text { know (8) }\end{array}$ & $\mathbf{n}$ & $\%$ & \\
\hline $\begin{array}{c}\text { Age (years): } \\
45-59 \\
60-74 \\
75-89\end{array}$ & $\begin{array}{c}15.3 \\
13.6 \\
1.6\end{array}$ & $\begin{array}{l}74.5 \\
62.9 \\
48.4 \\
\end{array}$ & $\begin{array}{c}8.2 \\
22.1 \\
40.3 \\
\end{array}$ & $\begin{array}{l}2.0 \\
1.4 \\
9.7\end{array}$ & $\begin{array}{c}98 \\
140 \\
62\end{array}$ & $\begin{array}{l}32.7 \\
46.7 \\
20.7\end{array}$ & 0.0000 \\
\hline $\begin{array}{c}\text { Sex: } \\
\text { Female } \\
\text { Male }\end{array}$ & $\begin{array}{l}10.2 \\
14.0 \\
\end{array}$ & $\begin{array}{l}61.3 \\
67.5 \\
\end{array}$ & $\begin{array}{l}25.8 \\
15.8 \\
\end{array}$ & $\begin{array}{l}2.7 \\
2.7 \\
\end{array}$ & $\begin{array}{l}186 \\
114 \\
\end{array}$ & $\begin{array}{l}62.0 \\
38.0 \\
\end{array}$ & non-significant \\
\hline $\begin{array}{l}\text { Place of residence: } \\
\text { Urban } \\
\text { Rural }\end{array}$ & $\begin{array}{l}12.2 \\
11.1\end{array}$ & $\begin{array}{l}68.9 \\
57.1\end{array}$ & $\begin{array}{l}16.5 \\
28.6\end{array}$ & $\begin{array}{l}2.4 \\
3.2\end{array}$ & $\begin{array}{l}164 \\
126\end{array}$ & $\begin{array}{l}56.6 \\
43.4\end{array}$ & non-significant \\
\hline $\begin{array}{c}\text { Marital status: } \\
\text { Single } \\
\text { Married } \\
\text { Widowed } \\
\text { Divorced } \\
\end{array}$ & $\begin{array}{c}24.1 \\
12.9 \\
1.7 \\
14.3\end{array}$ & $\begin{array}{l}55.2 \\
67.3 \\
53.3 \\
85.7 \\
\end{array}$ & $\begin{array}{c}20.7 \\
17.3 \\
40.0 \\
- \\
\end{array}$ & $\begin{array}{l}- \\
2.5 \\
5.0 \\
-\end{array}$ & $\begin{array}{c}29 \\
202 \\
60 \\
7 \\
\end{array}$ & $\begin{array}{c}9.7 \\
67.8 \\
20.1 \\
2.4 \\
\end{array}$ & - \\
\hline $\begin{array}{l}\text { Role in the family: } \\
\text { Grandfather } \\
\text { Grandmother } \\
\text { Father } \\
\text { Mother }\end{array}$ & $\begin{array}{l}13.2 \\
10.0 \\
16.2 \\
10.8\end{array}$ & $\begin{array}{l}63.2 \\
57.4 \\
75.7 \\
78.4\end{array}$ & $\begin{array}{c}21.0 \\
29.3 \\
5.4 \\
8.1\end{array}$ & $\begin{array}{l}2.6 \\
3.3 \\
2.7 \\
2.7\end{array}$ & $\begin{array}{c}76 \\
150 \\
37 \\
37\end{array}$ & $\begin{array}{l}25.3 \\
50.0 \\
12.3 \\
12.3\end{array}$ & 0.0263 \\
\hline $\begin{array}{c}\text { Employed: } \\
\text { Yes } \\
\text { No }\end{array}$ & $\begin{array}{c}19.0 \\
7.2\end{array}$ & $\begin{array}{l}71.6 \\
58.0\end{array}$ & $\begin{array}{c}8.6 \\
30.9\end{array}$ & $\begin{array}{l}0.9 \\
3.9\end{array}$ & $\begin{array}{l}116 \\
181\end{array}$ & $\begin{array}{l}39.1 \\
60.9\end{array}$ & 0.0000 \\
\hline
\end{tabular}

The self-assessment included the following categories: 'very high', 'high', 'moderate', 'low', 'very low' and 'I don't know'. Due to the small number of people with very 'high' and 'very low' scores, these results were included in the 'high' and 'low' categories, respectively. High levels of physical fitness were reported by $11.6 \%$ respondents, moderate by $63.7 \%$ and low by $22 \%$ of the respondents. Only $2.7 \%$ of the surveyed persons were not able to make an assessment. There was a statistically significant relationship between self-assessment and the age of the respondents. Moderate scores were most common (46.7\%), but their share declined with age, whereas the share of low scores increased with age. In the oldest group, more people who had difficulty selfassessing own physical fitness. The majority of the respondents were women (62\%), urban dwellers (56.6\%) and married (67.8\%). There was a large proportion of widowed people (20.1\%). Grandmothers accounted for $50.1 \%$ of the respondents, grandparents - half of that number (25.1\%), with the rest being parents (24.8\%). There was a statistically significant relationship between self-assessment of physical fitness and one's family role. Fathers and mothers was more often reported moderate physical fitness.

A statistically significant relationship was also observed between the scores and employment status. 39.1\% of the respondents were employed and assessed their fitness to be mainly high and moderate $(19 \%, 71.6 \%$ respectively). As stated above, the respondents reported primarily moderate fitness levels (Table 1). Such results were also predominant in all those who indicated their preferred forms of leisure time (Table 2). 
Table 2. Leisure activities and the self-assessment of physical fitness in the respondents ( $\chi^{2}$ test of independence)

\begin{tabular}{|c|c|c|c|c|c|c|c|}
\hline \multirow{2}{*}{ Leisure activities } & \multicolumn{2}{|c|}{ Self-assessment of physical fitness (\%) } & \multicolumn{3}{|c|}{ Total } & \multirow{2}{*}{ p for $\boldsymbol{\chi}^{2}$ test } \\
\cline { 2 - 8 } & High & Moderate & Low & $\begin{array}{c}\text { I don't } \\
\text { know }\end{array}$ & n & \% & non-significant \\
\hline Reading & 9.9 & 62.8 & 25.6 & 1.7 & 172 & 57.3 & non-significant \\
\hline Gardening & 10.5 & 68.0 & 18.3 & 3.2 & 153 & 51.0 & 0.0000 \\
\hline Physical recreation & 17.3 & 67.3 & 12.7 & 2.7 & 150 & 50.0 & non-significant \\
\hline Family visits & 10.5 & 63.4 & 23.9 & 2.2 & 134 & 44.7 & 0.0400 \\
\hline Meeting friends & 6.5 & 71.5 & 20.3 & 1.6 & 123 & 41.0 & non-significant \\
\hline Hobby & 14.7 & 63.2 & 21.1 & 1.0 & 95 & 31.7 & non-significant \\
\hline Social activism & 12.3 & 64.4 & 23.3 & - & 73 & 24.3 & 0.0242 \\
\hline Travelling & 8.2 & 78.1 & 12.3 & 1.4 & 73 & 24.3 & non-significant \\
\hline $\begin{array}{c}\text { University of Third } \\
\text { Age, Senior Clubs }\end{array}$ & 16.7 & 63.3 & 20.0 & - & 30 & 10.0 & \\
\hline
\end{tabular}

* The $\%$ table does not add up to 100 because the respondents could make several choices

The most frequently mentioned leisure activities included reading, gardening and physical recreation. In the latter case, that relationship was statistically significant. Those who participated in physical activity were slightly more likely to report their fitness as high and less likely to describe it as low. A substantial proportion of the respondents spent free time with their family (44.7\%), which resulted in low health assessments (23.9\%). A similar number preferred spending leisure time with friends (41.5\%), which caused that moderate and low scores dominated in this group. More than one-third of the respondents spent their leisure time pursuing own hobbies. Slightly fewer respondents declared social activism (24.3\%) and even fewer participated in University of the Third Age classes, Senior Clubs and other forms of activity (10\%). All those activities did not show any correlation with self-assessment of physical fitness, which however was visible in case of travelling. 78.1\% of those who had travelled within the previous 12 months declared moderate fitness, with $12.3 \%$ reporting low level of fitness. Respondents showed different behaviours towards physical activity and health care in the past (Table 3).

Table 3. Relationship between physical fitness and physical activity and pro-health behaviours in the past ( $\chi^{2}$ test of independence)

\begin{tabular}{|c|c|c|c|c|c|c|c|}
\hline \multirow[b]{2}{*}{ Physical activity } & \multicolumn{4}{|c|}{ Self-assessment of health (\%) } & \multicolumn{2}{|c|}{ Total } & \multirow[b]{2}{*}{$p$ for $\chi^{2}$ test } \\
\hline & High & Moderate & Low & $\begin{array}{l}\text { I don't } \\
\text { know }\end{array}$ & $\mathbf{n}$ & $\%$ & \\
\hline $\begin{array}{l}\text { Physical education } \\
\text { classes }\end{array}$ & 12.4 & 64.0 & 21.0 & 2.6 & 267 & 92.4 & non-significant \\
\hline Physical recreation & 12.9 & 65.8 & 18.7 & 2.7 & 225 & 75.3 & non-significant \\
\hline $\begin{array}{l}\text { Travelling (in the } \\
\text { previous year) }\end{array}$ & 15.3 & 71.7 & 11.8 & 1.2 & 170 & 66.9 & 0.0000 \\
\hline Rehabilitation & 9.0 & 60.2 & 28.3 & 2.4 & 166 & 67.5 & non-significant \\
\hline Sanatorium & 10.2 & 57.6 & 30.5 & 1.7 & 118 & 52.2 & non-significant \\
\hline $\begin{array}{l}\text { Holidays (within the } \\
\text { past } 12 \text { months) }\end{array}$ & 17.0 & 73.2 & 8.9 & 0.9 & 112 & 47.3 & 0.0000 \\
\hline Professional athlete & 20.5 & 69.2 & 9.0 & 1.3 & 78 & 26.2 & 0.0000 \\
\hline
\end{tabular}

The majority of the respondents had participated in physical education classes (92.4\%) and almost 3/4 in various forms of physical recreation. However, these activities did not impact the current self-assessment of physical fitness. Travelling in the last year, however, significantly correlated with the self-assessment of physical fitness. In this group, $71.7 \%$ rated their fitness as average, $15.3 \%$ as high and $11.3 \%$ as low. This form of activity, involving $66.9 \%$ respondents, was associated with physical fitness. More than half of them had undergone rehabilitation and sanatorium treatment, especially those reporting low fitness. Holiday trips were associated with higher self-reported fitness. There was also a significant correlation between previous athletic career and declared fitness. Former athletes reported high levels of physical fitness more than two times more often than low fitness. 
The relationships between self-assessments of physical fitness and leisure activities of the respondents with different socio-demographic characteristics were presented comprehensively using a multivariate analysis of correspondence (Figure 1), combined with the chi-square test of independence (Table 1,2).

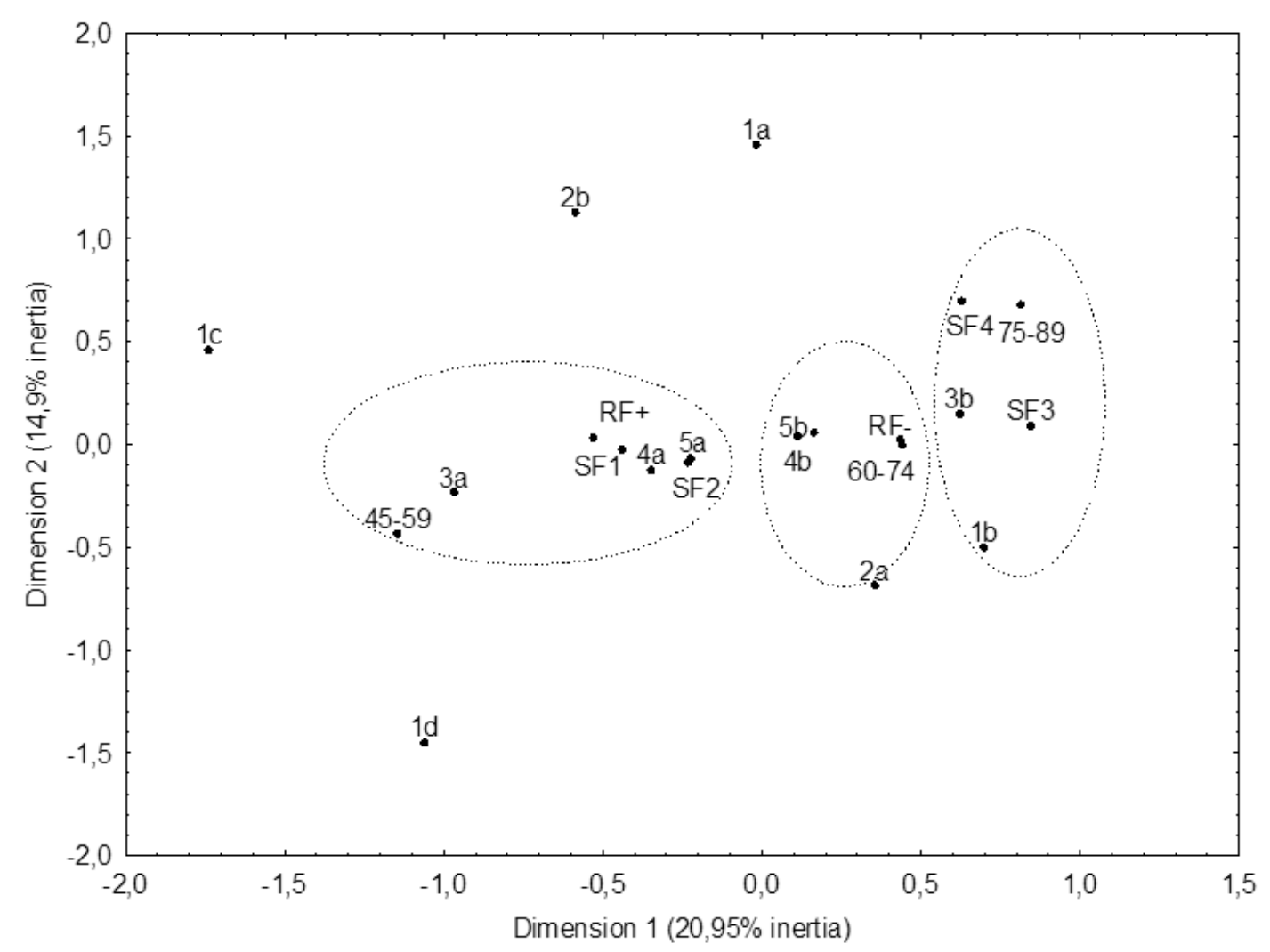

Figure 1. The relationship between self-assessment of physical fitness and leisure activities in the context of social determinants (multiple correspondence analysis - MCA)

The selected dimensions accounted for $35.85 \%$ of the total $\chi 2$. Two dimensions in space were taken into account in the graphic analysis, and the categories of self-assessment (SF1 - 'high', SF2 - 'moderate', SF3 - 'low', SF4 - 'I do not know'), age of patients (45-59, 60-74, 75-89 years), current participation (or lack thereof) in physical recreation (RF +; RF-) were established. People with high (SF1) and moderate (SF2) self-assessment of physical fitness more often participated in physical recreation (RF+), were employed (3a), preferred travel as a leisure activity (4a), as well as meetings with friends (5a), and were aged 45-59 years. Women (2a) who did not participate in physical activities (RF-), were aged 60-74, did not travel (4b) and did socialise in free time (5b). Those who rated their physical fitness as low (SF3) or unable to assess (SF4), were 75-89, did not work (3b), and played the role of the grandmother in the family (1b). Peripheral positions were occupied by grandparents (1a), fathers (1c), mothers (1d), and men (2b) (Figure 1).

The selected two dimensions (first and second) accounted for $36.07 \%$ of the total $\chi^{2}$. High (SF1) and moderate (SF2) self-assessment of physical fitness was reported by people aged 45-59, employed (3a), previously taking part in physical recreation (4a), travelling in the last 12 months (5a), going on holidays in the same period of time (6a), with some experience in competitive sport (7a), taking part in physical education classes in the past (8a).

Low assessment of fitness (SF3) was more often reported by people who were aged 75-89, did not travel in the last year (5b), as well as did not participate in physical education classes (8b) in the past.

An inability to self-assess physical fitness (SF4) was more often reported by women (2a) who were grandmothers (1b), unemployed (3b), had not participated in physical recreation in the past (4b), had not gone on holidays in the last year (6b), and had not been involved in competitive sport in the past (7b). The peripheral position was occupied by grandparents (1a), fathers (1c), mothers (1d), and men (2b) (Figure 2). 


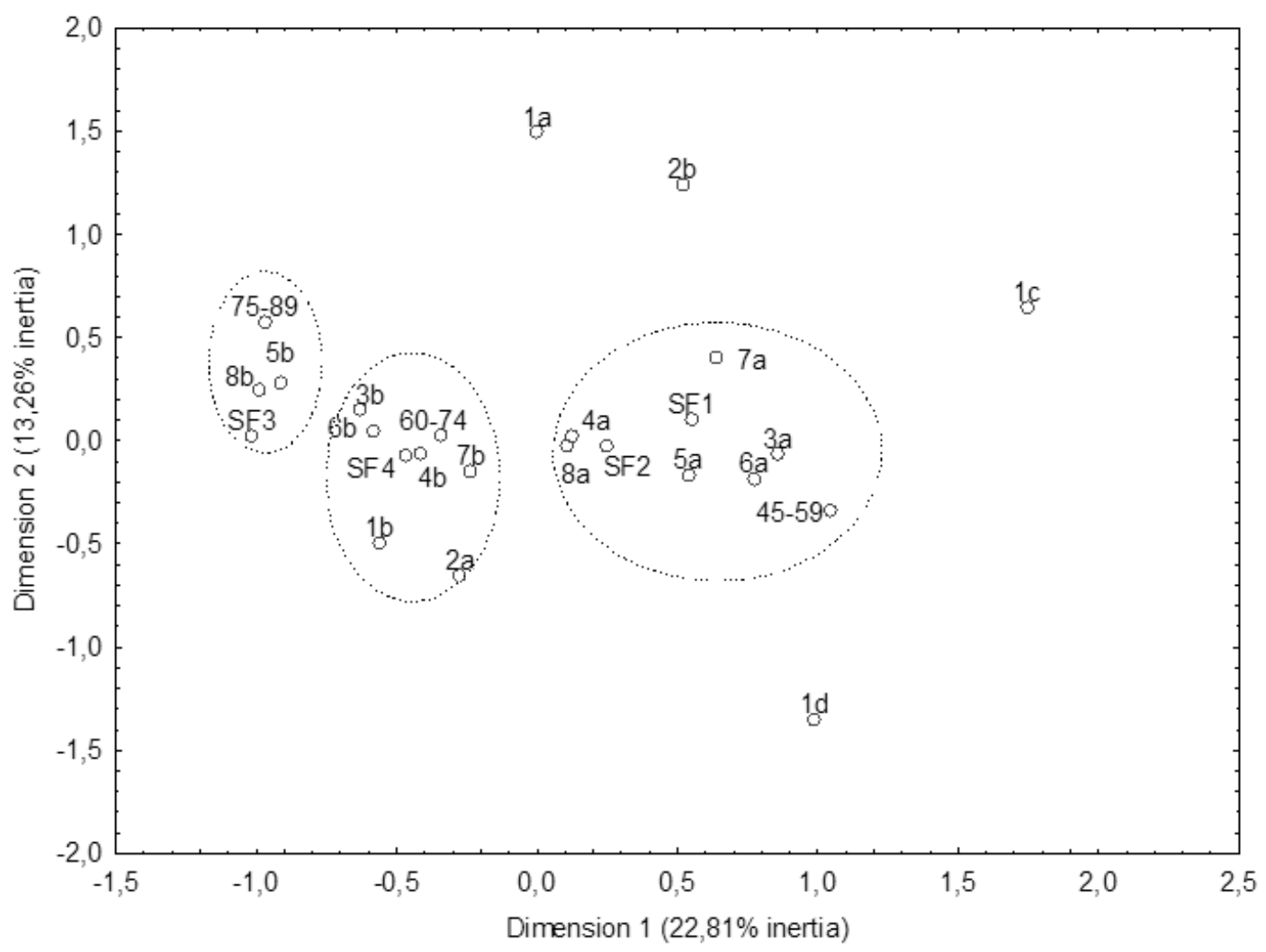

Figure 2. Relationship between self-assessment of physical fitness, physical activity, and health (MCA)

\section{Discussion}

Research shows that regular physical activity in the elderly is associated with the higher quality of life, enhanced motor abilities, increased self-reliance, better performance of daily duties and improved psychophysical well-being. Systematic physical activity not only decreases the death rate but also prolongs the period of independence and autonomy in daily life, and improves the quality of life of the elderly $[13,19,20]$. In our study, we showed that the self-assessment of physical fitness was age-related. Most of the respondents reported moderate scores (46.7\%), but this proportion decreased with age. The oldest group showed most difficulty in self-assessing their physical fitness. These problems - despite the low numbers of persons having such challenges - may be associated with diseases leading to reduced physical activity and deteriorated physical fitness. Their physical inactivity may have been caused by a worse state of health, disability, fear of exercise, and lack of specific pro-health habits in the former lifestyle periods.

The results of this study confirm [21] that no physical activity was reported more frequently in the oldest age groups, starting from the 65-69 group. A deficiency of physical activity in the early old age was reported by less than every other respondent, whereas in the group of $90+$ it was reported by 9 out of 10 . The decrease in regular and sporadic physical activity correlated with age. Those aged $80-84$ reported it to be $14.3 \%$ lower than in the 75-79 group. In addition, women were less active than men, and rural residents reported lower levels than urban dwellers. The age-related decline in physical activity, both among women and men, confirms the results of other studies from all over the world [22,23]. Older people also preferred less intensive forms of movement, tailored to individual capabilities. Most of the respondents went for regular walks, practised Nordic walking or attended organised activities. Currently, these are the most common forms of physical activity in the elderly [24].

The respondents involved in physical recreation demonstrated significantly higher self-assessment of physical activity. Moderate levels of fitness were more often reported by fathers and mothers, while low levels by grandfathers and grandmothers. This comes as no surprise as family roles are age-related. At the same time, the family environment offers a specific system of support and help. The family makes it easier for the elderly to adapt to old age, providing a sense of security and a source of emotional and financial support. A special role in the family is played by grandmothers, very influential figures in terms of pro-health behaviours in the young generation. A physically active grandmother who encourages family members to be active in leisure time is 
a lifelong asset, a person teaching the family how to assess own physical fitness and apply suitable exercise.

The elderly, even those who reach the late old age, often spend their free time helping in raising their grandchildren. These people highly value their lives, with physical fitness as the essential element that enables full participation in the family life [25].

In our study, we found a significant correlation between employment status and the self-assessment of physical fitness. $39.1 \%$ of the respondents were employed, and in this group, the scores were mainly high and moderate (19\% and $71.6 \%$ ), compared to the dominance of low and moderate values in the non-working group. In the study by K. Bałandynowicz-Panfil [26], 70\% of the persons working in the retirement age (whether entitled or not to receive a pension) described their fitness as good or very good, compared to $48 \%$ of those who worked and received a pension at the same time. Among the non-working elderly, the rate ranged from $7.6 \%$ in disabled pensioners to about $43 \%$ in non-working non-pensioners. In the group of pensioners, those who worked tended to report higher levels of health than those who did not.

Retirement changes a person's social role. It has a strong influence on their relationships, changes own selfassessment, and often prevents travelling. In our study, however, travels were one of the most preferred leisure activities. In addition, if in the earlier stages of their lives the respondents were highly active, had hobbies or engaged in volunteering, they were likely to continue and develop their pursuits after retirement. In the light of the statistical analyses [27], the active leisure of those living in the countryside is most often followed by people aged 65-69, acquiring new skills by people aged 55-59, whereas sport/physical activities - by people aged 5559 and 60-64 years. People who are motivated to go on tourist trips by health-related reasons are interested in health treatments such as rehabilitation treatments, massages, healing baths, weight loss diets, diet meals and participation in physical activity classes. The results of our research indicate that over half of the respondents had undergone rehabilitation and treatment at sanatorium within the last 12 months, especially those with low self-assessment of physical fitness. Holiday trips were associated with higher scores.

Furthermore, tourism of the elderly begins to play an increasingly important role in the tourist market as it is a group with considerable income and free time and a variety of preferences. It was found that about one-fifth of those $65+$ had gone for a tourist trip in the previous year, compared to $2 / 5$ in the entire study population. In the 65+ group, trips were mostly domestic (almost 75\%), i.e. visits to family, relatives, and friends (50\%) [27].

In our study, the self-assessment of physical fitness seemed to be a real indicator of physical activity and the ability of older people to perform various tasks. Its level is determined by various demographic, current and previous free-time preferences, but above all the current physical activity.

Deficiency of physical activity is one of the most significant modifiable risk factors for many diseases [28,29]. Therefore, pro-health education seems to be most natural and most effective measures aimed at improving the health status of the society [30]. Pro-health behaviours, especially physical activity, need to be propagated and promoted to enhance fitness and self-reliance of the elderly, resulting in successful ageing. It is also necessary to create comprehensive projects to activate the elderly and help them adapt to their changing needs and expectations.

\section{References:}

1. Milanović Z, Pantelić S, Trajković N, Sporiš G, Kostić R, James N. Age-related decrease in physical activity and funkcional fitness among elderly men and women. Clin. Interv Aging. 2013; 8: 549-556. https://doi.org/10.2147/CIA.S44112

2. Kim M, Lim S K, Shin S, Lee JH. The effects of objectively measured physical activity and fitness on fear of falling among Korean older women. J Exerc Rehabil. 2016; 12(5): 489-493. https://doi.org/10.12965/jer.1632716.358

3. Rizzuto D, Orsini, Qiu C Wang H , Fratiglioni L. Lifestyle, social factors, and survival after age 75: population based study. BMJ. 2012; 345: e5568. https://doi.org/10.1136/bmj.e5568

4. Wieczorowska-Tobis K. Dlaczego mężczyźni żyją krócej? Now Lek. 2012; 81(4): 386-389 (in Polish).

5. Hupin D, Roche F, Oriol M, Garet M, Pichot V, Gremeaux V. et al. Physical activity for older adults: Even a little is good! Ann Phys Rehabil Med. 2016; 59S: e58. https://doi.org/10.1016/j.rehab.2016.07.135

6. Nowak MA, Troczyńska N, Forjasz J, Nowak L. Chosen aspects oflifestyles of physically active women aged 4559 and 60-74. Health Problems of Civilization. 2016; 10 (3): 30-37. https://doi.org/10.5114/hpc.2016.61364

7. Kruk J. Health and Economic Costs of Physical Inactivity. Asian Pacific Journal of Cancer Prevention. 2014; 15(18): 7499-7503.

8. Łubkowska W, Szark-Eckardt M, Juszczyk A, Zając M, Stępień-Słodkowska M, Mroczek B, et al. Assessment of impact of the computer work station on the risk of musculoskeletal system diseases in banking sector employees. Lase Journal of Sport Science. 2016; 7(2): 93-106. 
9. Biernat E. Aktywność fizyczna mieszkańców Warszawy na przykładzie wybranych grup zawodowych. Warszawa: Oficyna Wydawnicza SGH; 2011 (in Polish).

10. Musich S, Wang S, Hawkins K, Greame C. The Frequency and Health Benefits of Physical Activity for Older Adults. Popul Health Manag. 2017; 20(3): 199-207. https://doi.org/10.1089/pop.2016.0071

11. Rütten A, Abel T, Kannas S, von Lengerke T, Lüschen G, Rodrigez DJ. Self reported physical activity, public health, and perceived environment: results from a comparative European study. J. Epidemiol. Com. Health. 2001; 55: 139-146. https://doi.org/10.1136/jech.55.2.139

12. Nowak M. Factors determining physical fitness self-evaluation and health self-evaluation in physically active women. New Med. 2006; 9(1): 19-25 (in Polish).

13. Kozdroń E, Kozdroń A. Rekreacja ruchowa a samodzielność w starości. Turystyka i Rekreacja 2005;1:166169 (in Polish).

14. Kotarska K, Wunsch E, Raszeja-Wyszomirska J, Kempińska-Podhorodecka A, Wójcicki M, Milkiewicz P. Leisure time physical activity and health-related behaviours after liver transplantation: a prospective, single centre study. Gastroenterology Review 2015; 2: 100-104. https://doi.org/10.5114/pg.2015.49002

15. Opdenacker J, Delecluse C, Boen F. The longitudinal effects of a lifestyle physical activity intervention on physical self-perceptions and self-esteem in older adults. Journal of Sport and Exercise Psychology. 2009; 31: 743-760.

16. Ferreira JP, Teixeira AM, Massart AG, Filaire E. Assesing self-esteem and perceived physical competence in elderly using the physical self-perception profile. European Journal of Adapted Physical Activity (EUJAPA). 2013; 6(2): 7-18.

17. Frołowicz T. Od oceny do samooceny sprawności fizycznej - propozycja modelu. In: Czyż S., editor. Wychowanie fizyczne w polskich i niemieckich szkołach. Wrocław: Akademia Wychowania Fizycznego we Wrocławiu; 2005. p. 61-65 (in Polish).

18. Van Buuren J, de Leeuw JV. Equality Constraints in Multiple Correspondence Analysis. Multivar. Behav. Res. 1992; 27 (4): 567-583.

19. Kotarska K, Wunsch E, Kempińska-Podhorodecka A, Raszeja-Wyszomirska J, Bogdanos D., Wójcicki M, et al. Factors affecting health-related quality of life and physical activity after liver transplantation for autoimmune and nonautoimmune liver diseases: a prospective, single centre study. Journal of Immunology Research. 2014; 1-9. https://doi.org/10.1155/2014/738297

20. Sygit K. Fundamental Significance of Physical Activity for Seniors' Health. Central European Journal of Sport Sciences and Medicine. 2015; 12(4): 53-59. https://doi.org/10.18276/cej.2015.4-06

21. Kantanista A, Król-Zielińska M, Szeklicki R. Aktywność fizyczna osób starszych z Wielkopolski w świetle ogólnopolskich badań PolSenior. Gerontologia Polska. 2013; 4: 113-118 (in Polish).

22. Ham SA, Yore MM, Fulton JE, Kohl HW. Prevalence of no leisure-time physical activity - 35 states and District of Columbia. Morbidity and Mortality Weekly Reports. 2004; 51(4): 82-86.

23. Katzmarzyk P. Physical activity and fitness with age among sex and ethnic groups. In: Bouchard C, Blair SN, Haskell W, editors. Physical activity and health. Champaign, Human Kinetics; 2007. p. 37-49.

24. Kaczmarczyk M, Trafiałek E. Aktywizacja osób w starszym wieku jako szansa na pomyślne starzenie. Gerontologia Polska. 2007; 15(4): 116-118 (in Polish).

25. Grzegorczyk J, Kwolek A, Bazarnik K, Szeliga E, Wolan A. Jakość życia osób mieszkających w domach pomocy społecznej i słuchaczy uniwersytetu trzeciego wieku. Prz Med Uniw Rzesz. 2007; 3: 225-233 (in Polish).

26. Bałandynowicz-Panfil K. Znaczenie aktywności zawodowej dla jakości życia osób starszych. In: Kałuża D, Szukalski P, editors. Jakość życia seniorów w XXI wieku: ku aktywności. Łódź: Wydawnictwo Biblioteka w Łodzi; 2010. p. 112-121 (in Polish).

27. Górna J. Preferencje i aktywność turystyczna Polaków w wieku 50+. Kultura Fizyczna 2015; 15(1): 153-166 (in Polish). https://doi.org/10.16926/kf.2015.14.11

28. Kruk J. Physical activity and health. Asian Pacific J Cancer Prev. 2009, 10: 721-728.

29. Niedzielska E, Guszkowska M, Kozdroń E, Leś A, Krynicki B, Piotrowska J. Quality of life and its correlates in students of a University of the Third Age. Pol. J. Sport Tourism 2017, 24: 35-48. https://doi.org/10.1515/pjst-2017-0005

30. Piech K. Promocja rodzinnej aktywności ruchowej. Biała Podlaska: Wydawnictwo AWF JP ZWWF; 2004 (in Polish). 